(C) 1991 ISIJ

/IIIIIIIIIIIIIIIII

論 文

|/IIIIII/IIIIII/I/

熱間圧延における高圧水脱スケール時の

衝突圧

和田 忠義 ${ }^{*} \cdot$ 上田 正雄 ${ }^{* 2} \cdot$ 押見 正一 $* 3$

\title{
Impact Pressure of Water in Hydraulic Descaling during Hot Strip Mill Rolling
}

Synopsis :

Tadayoshi WADA, Masao UEdA and Masakazu OSHIMI

Hydraulic descaling is commonly used to remove scale formed during reheating and continuous rolling of steel strips.

On an experimental survey of parameters which affect the descaling behaviour, impact pressure was measured precisely both by spraying over a plasticine (a modelling material) on the basis of design of experiments and by using a pressure converter. It was found that the impact pressure has good correlations with the water consumption $V$ at a pressure of $9.8 \mathrm{MPa}$, water pressure $P$, rolling speed $v$ and distance $H$ between the material and the nozzle.

The thickness loss $\Delta t$ of plasticine and the impact pressure $p$ by hydraulic descaling can be then expressed by the descaling parameters as follows;

$\Delta t=2000 \mathrm{PV} /\left(v \mathrm{H}^{2}\right)(\mathrm{cm}$, correlation coefficient : 0.94$)$

$p=5.64 \mathrm{PV} / \mathrm{H}^{2}(\mathrm{MPa})$

The impact pressure calculated from the equation is in excellent agreement with $H$. HoJAs results.

Since the impact pressure required to remove the primary scale is much higher than secondary scale, a careful set up of the conditions is essential to complete the descaling.

Key words : hydraulic descaling; impact pressure; primary scale; secondary scale.

\section{1. 緒}

\section{言}

薄鋼板の製造に際し，鋳片を加熱および熱間圧延中に 生成した酸化スケールは，表面疪の原因となるため，高 圧水装置で脱スケールされ，スケール疵のない清浄な表 面の鋼板が製造される。高压水による脱スケール性は, スケール皮膜の性状と高圧水の噴射条件との関係が強い と考えられる.

R.F. TYLECOTE ら ${ }^{1)}$ は, 高温鋼材のスケール密着性に 及ぼす要因について報告しており，中でも鉄と鉄酸化物 の体積比 : Pilling-Bedworth (P-B) 比 ${ }^{2)} に$ 重点をおい ている.

脱スケールに関する研究では, 松野 ${ }^{3)}$ は, 高温鋼材の スケールのブリスターが脱スケール性に影響を及ぼすと している. しかし，脱スケール時の水压力は $1 \mathrm{MPa}$ 以 下であり，熱延「場で通常脱スケールに使用されている 水圧力の約 $15 \mathrm{MPa}$ に比べて約 1 桁も低く, 十分なシ
ミュレーションになっていない.

次に, $T$. SHEPPARI $ら^{4)}$ は, 高温鋼材の脱スケール機 構について, (1)高压水による急冷作用, (2)破壊作用, (3) 爆発作用および(4)スケール皮膜の成言による压緬心力な どにより脱スケールされるとしている.

この中で, 急冷, 破壊および䇰発作用については, 高 压水を噴射時の水压力, ノズル流水量およびノズルの取 付け位置などの高压水の噴射条件との関係が強いと考え られる。しかし，これらの要闪については不明な点が多 い。ここでは，高压水の噴射条件を表すパラメーターと して衝突压を用いて検執することにした。

高压水を噴射時の衝突府につつては，H. HoJAS ら ${ }^{5)}$, $W$. Herold ${ }^{6)}$ および $O$. HenNIG ら ${ }^{7)}$ の研究がある。これ らはいずれも衝突压の計算式を提唱しているが，統一的 な式がなく，しかも実用的でない. かつ，各要因の知与 率が不明で，多くの場命定性的な対心がとられてきた。

したがって，高压水を噴射時の衝突压に及ぼす各種要

平成 2 年 9 月本会講演大会にて発表 平成 2 年 3 月 26 日受付 (Received Mar. 26, 1990)

* 新日本製鉄 (株)鉄銅研究所 (現: 新日本製鉄(株)人事部) (Steel Research Laboratories, Now Personnel Division, Nippon Steel Corp.)

*2 新日本製鉄(株)堺技術研究部（現：木夕二商事(株)）（Sakai R \& D Lab., Nippon Steel Corp., Now Hotani Co., Ltd.）

*3 新日本製鉄(株)鉄鋼研究所 (Steel Research Laboratories, Nippon Steel Corp., 20-1 Shintomi Futtsu 299-12) 
因の影響を明らかにし，定量化することが重要であると 考えられる。

一お，衝突压:の測定には，一般に面压計が使用されて いるが, 衝突泊i積を正確，かつ，谷易に測定するために， 衝突面の而庯パターンを観祭しやすいプラスティシン8) を供試材に用いるおがよいと考えた。 そこで，今回，高 溫鋼材に似た塑性変形をする白色プラスティシンを用い て，高成による厚みの減少量を測走し，さらに，面压 計を用いて高店水を喷射時の衝突压を測定し，各種要因 との関係の数式化を試みた。

\section{2. 実 験 方 法}

\section{$2 \cdot 1$ 供試材}

供試材は, 高温鋼材に似た塑性変形をする白色プラス ティシン ${ }^{8)}$ (粘土状物質, 炭酸カルシウム, 鉱物質, 石 嶮, 油脂, 脂肪酸などを含む, 比重 $1.8,15^{\circ} \mathrm{C}$ での剪 断強さ $83 \mathrm{kPa}$ )を使用した.これを石育ロールで成形し， 高压水の衝突面積よりやや大きめの厚み 3.0 , 幅 22 , 長さ $6.6 \mathrm{~cm}$ の寸法に仕上げた.

\section{$2 \cdot 2$ 高圧水によるプラスティシンの厚み減少量に及ぼ す要因の調查}

高压水噴射装置 TS-30AHF 型（最大压力 $9.8 \mathrm{MPa}$,

Table 1. Experimental conditions of hydraulic descaling.

\begin{tabular}{|c|c|c|c|c|}
\hline Factor & & Unit & Level & Remarks \\
\hline $\begin{array}{l}\text { Water pressure } \\
\text { Water consumptjon at } \\
\text { a pressure of } 9.8 \mathrm{MPa} \\
\text { Rol ling speed } \\
\text { Distance between } \\
\text { material and nozzle } \\
\text { Gradient angle } \\
\text { Descal ing direction }\end{array}$ & $\begin{array}{l}\text { P } \\
y \\
H \\
\theta \\
D\end{array}$ & $\begin{array}{l}\mathrm{MPa} \\
1 / \mathrm{s} \\
\mathrm{cm} / \mathrm{s} \\
\mathrm{cm} \\
-\end{array}$ & 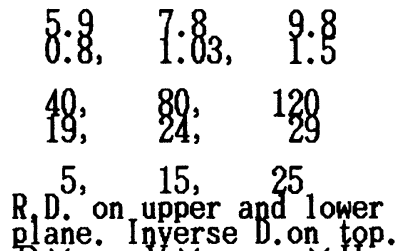 & $\begin{array}{l}\text { Water temp. } 13^{\circ} \mathrm{C} \\
\text { Room temp. } 12^{\circ} \mathrm{C} \\
\text { R.D. on ypper plane }\end{array}$ \\
\hline Interaction & & - & 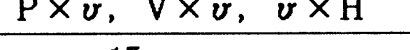 & \\
\hline $\begin{array}{l}\text { Angle of torsion } \\
\text { Spraying angle } \\
\text { Jet width } \\
\text { Oescaling No. } \\
\text { Orthogonal table }\end{array}$ & $\begin{array}{l}\delta \\
z\end{array}$ & $\begin{array}{c}\dot{ } \\
\text { times }\end{array}$ & $\left\{\begin{array}{l}15 \\
2 \mathrm{H}_{\mathbf{2 7}}\left(3^{13}\right)=27\end{array}\right.$ & $\delta$ \\
\hline
\end{tabular}

Table 2. Plans $\mathrm{L}_{27}\left(3^{13}\right)$ and results.

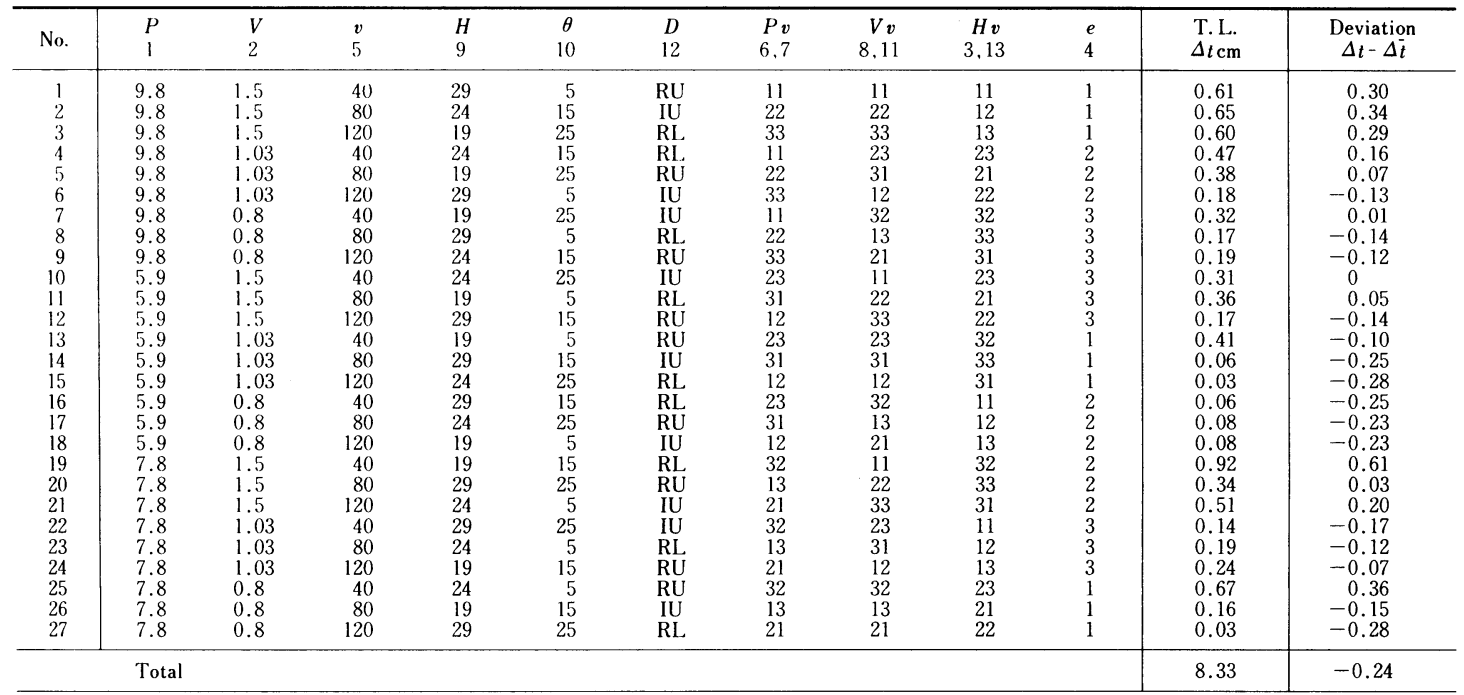

R \& I : Rolling and Inverse Direction U \& L : On Upper and Lower Plane T. L. : Thickness Loss of Plasticine 

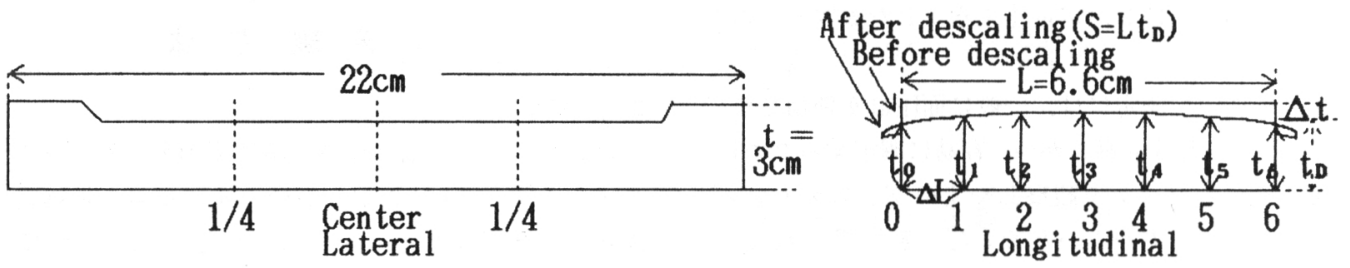

Fig. 1. Schematic illustration of cross sectional shape of plasticine after hydraulic descaling test.

最大流量 $100 \mathrm{l} / \mathrm{min}$ ) を用いて，上記供試材に高圧水を 噴射後の厚み減少量を測定した。 Table 1 に高圧水の噴 射条件を示す。それらの要因として，水圧力 $P(\mathrm{MPa})$, ノズル流水量 $V(\mathrm{l} / \mathrm{s})$, ノズルと供試材間の垂直距離 $H$ $(\mathrm{cm})$, 傾斜角 $\theta\left(^{\circ}\right)$, 㨝り角 $\delta\left(^{\circ}\right)$, 噴射方向 $D$ 抢よび 通板速度 $v(\mathrm{~cm} / \mathrm{s})$ を実験計画法 $\left.{ }^{9}\right)$ による $\mathrm{L}_{27}\left(3^{13}\right)$ の直 交表で解析した。 Table 2 に各要因のわりつけを示す. ここで，厚み減少量を大きくするため，噴射回数をそれ ぞれ 10 回とした。さらに，Fig. 1 に示すように，高圧 水を噴射後のプラスティシンの厚み減少量 $\Delta t$ は, 初期 厚み $t(\mathrm{~cm})$ と高压水を噴射後の幅方向中央部の平均厚 み $t_{D}(\mathrm{~cm})$ との差として計算した。ここで, 高圧水を 噴射後のプラスティシンの断面積 $S\left(\mathrm{~cm}^{2}\right)$ は, 幅方向 中央部の断面を長手方向に 6 等分し, シンプソンの公式 で計算した。すなわち,

$$
S=(\Delta L / 3)\left\{t_{0}+4\left(t_{1}+t_{3}+t_{5}\right)+2\left(t_{2}+t_{4}\right)+t_{6}\right\}
$$$$
\Delta t=t-t_{D}=t-S / L \text { である. }
$$

ここで， $\Delta L$ は供試材の長さの 6 分の $1, t_{0}, t_{1}, t_{2}$, $t_{3}, t_{4}, t_{5}$ および $t_{6}$ は高圧水を噴射後の供試材の厚み, $L$ は供試材の初期の長さである.

\section{$2 \cdot 3$ プラスティシンの厚み減少量に及ぼす垂直距離お よびノズル流水量の影響調查}

高圧水を噴射する際の前記各要因の中で，熱延ライン で比較的に管理しやすい要因は，垂直距離およびノズル 流水量である.

そこで，プラスティシンの厚み減少量に及ほす垂直距 離およびノズル流水量の影響を調査した。すなわち,

Table 3 に示すように，ノズルが DNB1830 の時，水圧 力は $7.8 \mathrm{MPa}, \mathrm{DNB} 1530,1132$ および 0830 の時, 9.8

Table 3. Effect of distance between material and nozzle on impact force by hydraulic descaling.

\begin{tabular}{r|c|cccccc}
\hline Nozzle & $P($ MPa $)$ & \multicolumn{5}{c}{$H(\mathbf{c m})$} \\
\hline DNB 1830 & 7.8 & 19 & 22 & 25 & 28 & 31 & 34 \\
1530 & 9.8 & 19 & 22 & 25 & 28 & 31 & 34 \\
1132 & 9.8 & 19 & 22 & 25 & 28 & 31 & 34 \\
0830 & 9.8 & 19 & 22 & 25 & 28 & 31 & 34 \\
\hline$v=80 \mathrm{~cm} / \mathrm{s} \quad \theta=15^{\circ}$ & $D:$ R. D. on top plane
\end{tabular}

$\mathrm{MPa}$ とした。ここで, 垂直距離は $19 \sim 34 \mathrm{~cm}$ の範囲で $3 \mathrm{~cm}$ 間隔とし, 通板速度は $80 \mathrm{~cm} / \mathrm{s}$, 傾斜角 $15^{\circ}$ およ び噴射方向は上面の正方向で一定にした。

\section{$2 \cdot 4$ 高圧水を噴射時の衝突圧の測定}

高圧水を噴射時の衝突圧を面圧計で測定した。測定条 件は，ノズルは DNB1530, 垂直距離は $28 \mathrm{~cm}$ で, 水压 力は $9.8 \mathrm{MPa}$ である。また，面圧計の受压面は 20 $\mathrm{cm} \phi$ で圧力変換器を用いて測定した。 なお, 衝突面積は, プラスティシンを静止させた状態で高圧水を $6 \mathrm{~s}$ 噴射 後, その山み部から求めた。

\section{3. 実 験 結 果}

\section{$3 \cdot 1$ プラスティシンの厚み減少量に及ぼす高圧水の噴 射条件の影響}

Photo. 1 に高压水を噴射後のプラスティシンの厚み 減少状況を示す。プラスティシンの厚み減少量は幅方向 の中央部で最大で，長さ方向では頭部および尾部が中央 部よりやや大きい。ここで, Table 2 に示した厚み減少 量は幅方向の中央部での測定值を代表值とした。

次に, プラスティシンの厚み減少量に及ぼす高圧水の 噴射条件の各要因の影響を Fig. 2 に示す。また, Table 2 のデータをもとに分散分析を行った結果を Table 4 に示す.
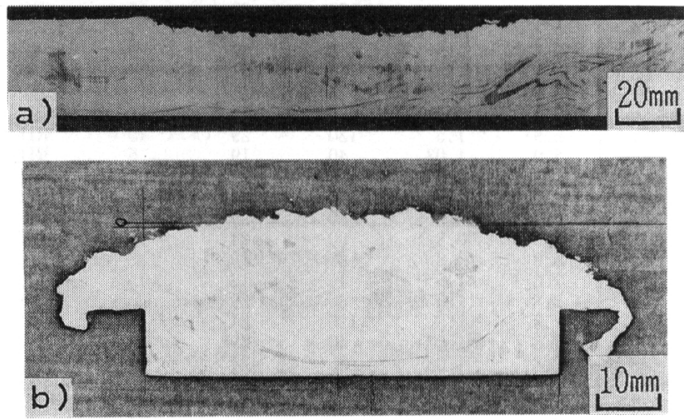

a) Lateral section b) Longitudinal section

Photo. 1. Results of descaling test carried out on plasticine (Test No. 2). 


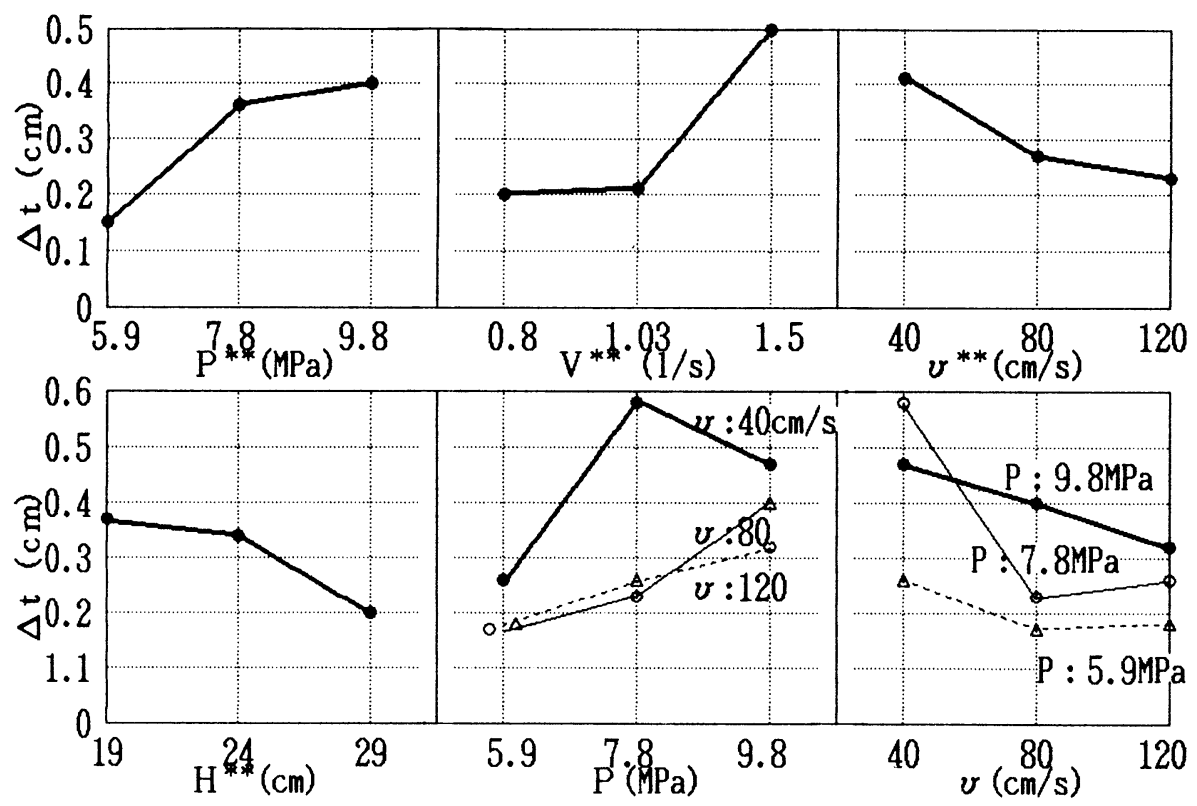

Fig. 2. Effect of descaling conditions on thickness loss of plasticine.

Table 4. Analysis table of variance.

\begin{tabular}{c|c|c|c|c|c|c}
\hline Factor & $\begin{array}{c}\text { Fluctuation of } \\
\text { each unit } \\
S\end{array}$ & $\begin{array}{c}\text { Degree of } \\
\text { freedom } \\
f\end{array}$ & $\begin{array}{c}\text { Variance } \\
V\end{array}$ & $\begin{array}{c}\text { Variance } \\
\text { ratio } \\
F\end{array}$ & $\begin{array}{c}\text { Pure } \\
\text { fluctuation } \\
S^{\prime}\end{array}$ & $\begin{array}{c}\text { Contribution } \\
\text { rate } \\
\rho\end{array}$ \\
\hline$P$ & 0.31 & 2 & 0.156 & $14.7 * *$ & 29.0 & 20.7 \\
$V$ & 0.52 & 2 & 0.259 & $24.4^{* *}$ & 49.6 & 35.4 \\
$v$ & 0.17 & 2 & 0.087 & 9.0 & 15.3 & 11.6 \\
$H$ & 0.15 & 2 & 0.077 & $7.3^{* *}$ & 14.3 & 10.3 \\
$P v$ & 0.10 & 0.026 & 2.5 & 8.4 & 6.0 \\
$e$ & 0.15 & 14 & 0.011 & & 22.4 & 16.0 \\
\hline Total & 1.40 & 26 & & & & 100 \\
\hline ***
\end{tabular}

プラスティシンの装み減少望に及ぼす高长:水喷射条件 の各要过のうち, ノズル流水里 $V$, 水性打 $P$, 通板速

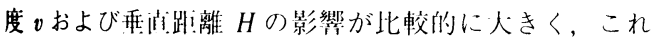
らの各要刚はそれぞれ $1 \%$ 们意である。ただし，傾斜 角 $\theta$, 墳射方向 $D$, ノズル流水量 $V$ と通极速度 $v$ との

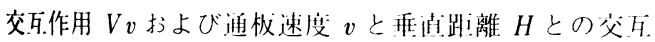
作用 Hvの変動が小さいので，善にプールした，

次に, Table 4 の分散分析絬果から要凷の効果を推足 する，信頼限界は，信赖位を $95 \%$ として，缋差の分散 $V_{e}=0.01$, その目渡 14 , 冬要因の自由度 1 の $\mathrm{F}$ 表 の $5 \%$ 值は 4.60 であるので, 各要闪の有効处覆数 $n_{e}$ $=9$ または 3 を代人すると，

$$
\begin{aligned}
\pm \sqrt{F V_{e} / n_{\rho}}= & \pm \sqrt{4.60 \times 0.01 / 9}= \pm 0.07 \text { または } \\
& \pm \sqrt{4.60 \times 0.01 / 9}= \pm 0.12
\end{aligned}
$$

となる.すなわち, Fig. 2 にふしたプラスティシンの
厚み減少量 $\Delta t$ に及ぼす各要因の中で，有効反覆数が 9 であるノズル流水量 $V$, 水压力 $P$, 通权速度 $v$ および 垂直距離 $H$ は，それぞれの水準で $0.07 \mathrm{~cm}$ ，また，有 効父覆数が 3 の水压力 $P$ と通板速度 $v$ の交互作用 $P v$ については $0.12 \mathrm{~cm}$ で示される範用の信頼度が $95 \%$ である。

\section{$3 \cdot 2$ プラスティシンの厚み滅少量に及ぼす垂直距離お よびノズル流水量の影響}

Fig. 3 にプラスティシンの厚み減少量に及ぼす垂值 距離の影響をノズル流水量別に示す。いずれの曲線も厚 みの減少量 $\Delta t$ は垂直距離 $H$ の二乗に取比例している ようであり，ノズル流水量が大きくなると増加する傾们 を示している．阊中でノズル流水量が大きい DNB1830 では，垂直距離が 19 および $22 \mathrm{~cm}$ で $\Delta t$ がやや減少し ているようである。この原因は，水流がプラスティシン 


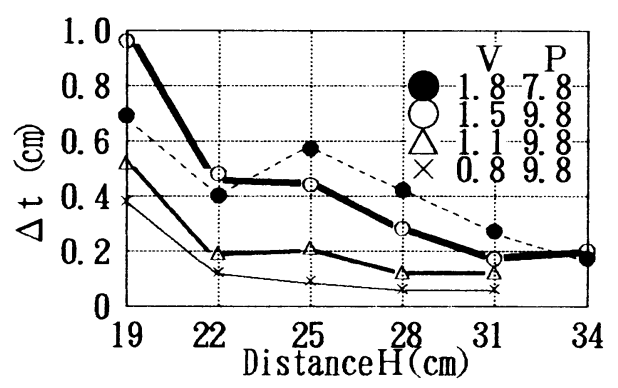

Fig. 3. Effect of distance between material and nozzle on thickness loss of plasticine.

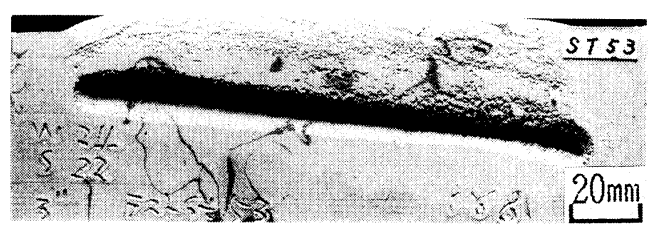

Photo. 2. Plane view of concaved profile of plasticine deformed by high pressure water from descaling nozzle $(P=9.8 \mathrm{MPa}$, Nozzle $1530, H=28$ $\mathrm{cm}$, spraying time : $6 \mathrm{~s})$.

に衝突した際，吹き飛ばされてその後百に学く盛り上 がったためと考えられる。

\section{$3 \cdot 3$ 高圧水噴射時の衝突圧}

ノズル DNB1530, 垂㨁距離 $28 \mathrm{~cm}$, 水非力 $9.8 \mathrm{MPa}$

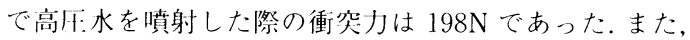
この条作で高永を $6 \mathrm{~s}$ 墳射後のプラスティシンの叫み 状沉を Photo. 2 に永す。この時のプラスティシンの山 み部（幅 $15.5 \mathrm{~cm}$, 埌さ $1.2 \mathrm{~cm}$ ) の佰積から衝突庄を 計算すると, $106.5 \mathrm{kPa}$ となる。

\section{4. 考察}

\section{$4 \cdot 1$ プラスティシンの厚み隇少量に及ぼす各種要因と の関係}

Table 2 のデータをもとに, プラスティシンの厚み減 少量 $\Delta t$ に及ぼす竒与率の大きい 4 要因との重相関式を 求め，次式が得られた。重相関係数は78\%である。

$$
\Delta t=1040 \mathrm{PV} /\left(v H^{2}\right) \cdots \cdots \cdots \cdots \cdots \cdots \cdots \cdots \cdots \cdots \cdots \cdots \cdots \cdots \cdots \cdots
$$

ガ，3・2 節で垂值距離の影響を調查したデー夕をも とに, 前記の 4 要因との重相関式を求め, 次式が得られ た。重相関係数は $94 \%$ である。

$$
\Delta t=2000 P V /\left(v H^{2}\right) \text {. }
$$

ここで, 式( 1 ) および式( 2 )には傾斜角の要因を取り 人れるべきであるが，通常使用されている範网ではこの
影響が小さいため，詋养の落刚になっていると考えられ る。また，式（1）の重相関係数が低くなった理服として，

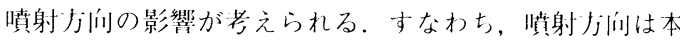
米，供试材と高压：水との相对的な衝突速度の要闪とみな すべきであり，膹流の流速に命まれると考えたほうがよ

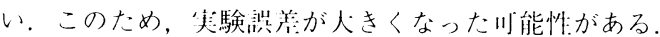

\section{$4 \cdot 2$ 高圧水噴射時の衝突圧の計算}

$3 \cdot 3$ 節で得られた衝突川:は $106.5 \mathrm{kPa}$ であったこの

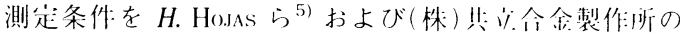
技術資料 ${ }^{10)}$ の計算式に適用して衝突川:を求めると，い づれも $107.9 \mathrm{kPa}$ となり，本研究絬果とよく一致する.

また、今回求めた式( 2)のプラスティシンの皆み減少 量は高戊水噴射時の衝突川が大きくなるほどきくな り，脱スケール性が发好になると券えられる。そこで，

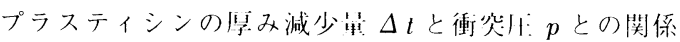
を測足した絬果を Fig. 4 に小村。Fig. 4 から， $\Delta t$ は $p$ および $\mathrm{l} / v$ に比例し，次式で表せることがわかった。 こで， $p$ が約 $60 \mathrm{kPa}$ 以下で $\Delta \ell$ が減少しているが，プ ラスティシンの剪断強さ到以下になたためと考えられ 万.

$$
\Delta t \doteqdot 354.6 \mathrm{p} / \mathrm{v}
$$

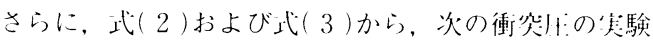
式が得られた。

$$
p \fallingdotseq 5.64 P V / H^{2}(\mathrm{MPa})
$$

次に，式(4)および H. HoJAS ら ${ }^{51}$ の衝突川!の計算式 を用いて各種噴射条俳での衝突川：胡算した結果を Table 5 掞よびFig. 5 にホす寸。咑式による衝突原の計 算結果はきわめてよく・敨している。参考までに，

H. HOJAS ら ${ }^{5)}$ の衝突庇の算式を以下に小寸。

$$
\begin{aligned}
& p=P t / f=20.63 \mu \mathrm{FP} / f \quad \cdots \cdots \cdots \cdots \cdots \cdots \cdots \cdots \cdots \cdots \cdots \cdots \\
& \text { ただし， } 5)^{5)}
\end{aligned}
$$

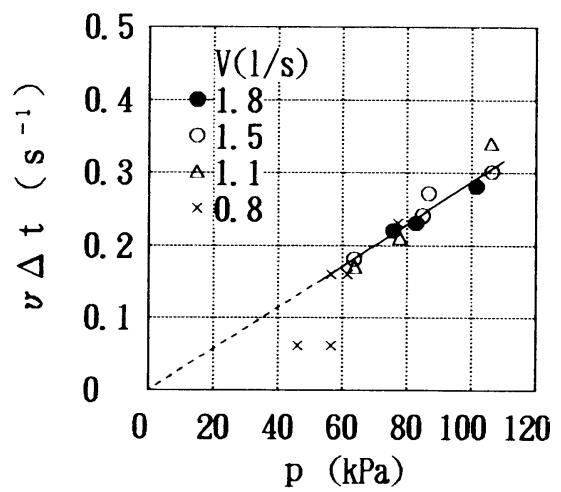

Fig. 4. Relation between impact pressure and thickness loss of plasticine. 
Table 5. Calculated impact pressure at various water pressures.

\begin{tabular}{|c|c|c|c|c|c|c|c|c|c|}
\hline Reference & Scale & $V(\mathrm{l} / \mathrm{s})$ & $H(\mathrm{~cm})$ & 9.8 & $\begin{array}{r}\mathrm{Wa} \\
12.3\end{array}$ & $\begin{array}{l}\text { ressur } \\
14.7\end{array}$ & $\begin{array}{l}(\mathrm{Pa}) \\
17.2\end{array}$ & 19.6 & $\begin{array}{l}\text { Required impact } \\
\text { pressure }(\mathrm{kPa})\end{array}$ \\
\hline $\begin{array}{l}\text { H. Ho.JAs } \\
\text { Present work }\end{array}$ & Ist & 2.3 & 35 & $\begin{array}{l}118 \\
104\end{array}$ & $\begin{array}{l}136 \\
129\end{array}$ & $\begin{array}{l}164 \\
156\end{array}$ & $\begin{array}{l}191 \\
181\end{array}$ & $\begin{array}{l}218 \\
208\end{array}$ & $\geqq 167$ \\
\hline $\begin{array}{l}\text { H. HoJAs } \\
\text { Present work }\end{array}$ & lst & 2.3 & 30 & $\begin{array}{l}151 \\
141\end{array}$ & $\begin{array}{l}184 \\
177\end{array}$ & $\begin{array}{l}223 \\
212\end{array}$ & $\begin{array}{l}259 \\
247\end{array}$ & $\begin{array}{l}297 \\
282\end{array}$ & $\geqq 186$ \\
\hline $\begin{array}{l}\text { H. HoJAs }{ }^{5)} \\
\text { Present work }\end{array}$ & 2nd & 1.5 & 30 & $\begin{array}{l}97 \\
92\end{array}$ & $\begin{array}{l}121 \\
116\end{array}$ & $\begin{array}{l}148 \\
138\end{array}$ & $\begin{array}{l}173 \\
162\end{array}$ & $\begin{array}{l}196 \\
184\end{array}$ & $\geqq 59$ \\
\hline
\end{tabular}

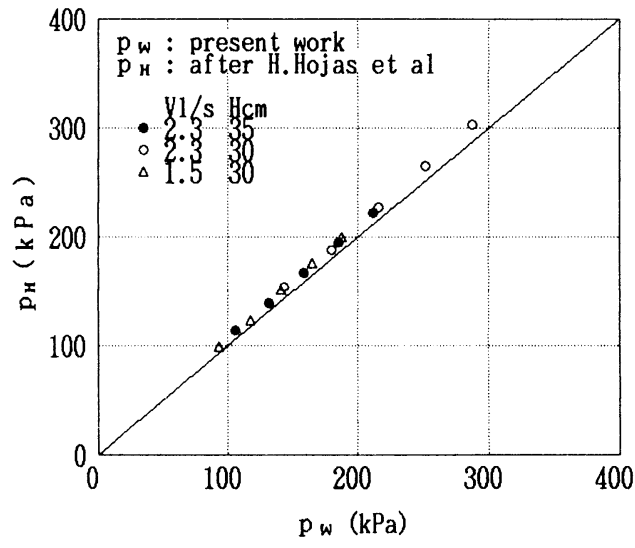

Fig. 5. Relation between calculated impact pressure by present work and $H$. HoJAs et al. ${ }^{5)}$.

流速 $c=4.54 \sqrt{g P / \rho}$ である。また， $\mu$ は噴射係数 $(一)$, $F$ はノズルの断闰積 $\left(\mathrm{m}^{2}\right), f$ は衝突面積 $\left(\mathrm{m}^{2}\right)$ および $\mathrm{g}$ は重力加速度 $\left(\mathrm{m} / \mathrm{s}^{2}\right)$ である。

式( 5 )式は，いずれも水流量 $Q$ またはこれに関する $\mu, F$ および $f$ なとの愐目をあらかじめ測定しておく必 要があるため，尖用にはやや不便である。

したがって, 式( 4 )は, 水卡力 $P$, ノズル流水量 $V$ および垂消距離 $H$ の 3 要四から衝突压を求めることが できる簡便式であり，式( 5 )に比べて実用的である.

\section{$4 \cdot 3$ 高圧水噴射時の衝突圧と脱スケール性の検討}

高压水による脱スケールの適正条件を推分するには, (1)高温鋼材の脱スケール性を高め, かつ，(2)鋼材の温度 低下を小さくすることが車要である。ここでは(1)のみを 検討し，次報 ${ }^{11)}$ で総令的に検㗅する.

先に，水版 $9.8 \mathrm{MPa}$ ，ノズル DNB1530 および垂 值距離 $28 \mathrm{~cm}$ での衝突店は $106.5 \mathrm{kPa}$ であると報告し た。た，今叫，薯者らが低炭素鋼の二次スケールの脱 スケールに必要な最低衝突压を倜査したところ， $35 \mathrm{kPa}$ が得られた。

この值は，O. HeNNIGらら が求めた普通鋼揖よび低命 金鋼の熱開压延における二次スケールの脱スケールに必
要な衝突压の約 50〜80 kPa に近い，したがってこの 衝突压は，低炭素鋼の二次スケールの脱スケールに対し ては十分な值と考えられる。

-一方，W. HEROLD ${ }^{6)}$ は，鋼種が不明であるが，熱延鋼 板および条鋼材での二次スケールの脱スケールに必要な 衝突压を求め，200４00 kPa を推奖している。この報 告での最低衝突压は著者らの值に比べて約 1 析高い。こ の理由は，脱スケールが難しい条鋼材での衝突厘を目㚣 にしているためと考えられる。この衝突圧を得るに は，前記の高压水噴射条件では不十分で，ノズルに DNB1530を使用し，水压力 $P$ を $14.7 \mathrm{MPa}$ に増加した 場合，垂直距離 $H$ は約 $18 \mathrm{~cm}$ 以下にする必要がある.

次に, 一次スケールについては, H. HoJAS ら ${ }^{5)}$ は普通 鋼，低および高合金鋼においては最低約 $400 \mathrm{kPa} の$ 衝 突压が必要であるとしている。また，W. HEROLI ${ }^{6)}$ は $400 \sim 2000 \mathrm{kPa}$ および $O$. HenNIG ら ${ }^{7)}$ は $200 \sim 250 \mathrm{kPa}$ 以上の衝突厈を推奨している。この值は二次スケールの 脱スケールに必要な衝突压の約 2〜5 倍も高い.

この理由は，一次スケールはきわめて厚いため，二次 スケールに比べて高压水によるスケールと地鉄の界通の 急冷作用が起こりにくいこと，ヴスタイト $(\mathrm{FeO})$ は高 温ほど塑性変形しやすい'12)ことおよび合金鋼では加熱 中に生成したサブスケールの投錨作用により剥離しにく くなっていることなどが考えられる.

以上を Table 6 に要約して示す。これから, 一次ス ケールを除去するために必要な衝突压は，12\% Cr 鋼の ような高合金鋼の場命には約 $400 \mathrm{kPa}$ 以上, 普通鋼拀 よび低合金鋼の場合には約 $250 \mathrm{kPa}$ 以上と考えられる.

そこで，この衝突压を得るための条件を検討する。た とえば, 式( 4 )の水压力 $P$ を $14.7 \mathrm{MPa}$ およびノズル 流水量 $V$ を $2.3 \mathrm{l} / \mathrm{s}$ として, $400 \mathrm{kPa}$ 以上の衝突压を得 るには，垂值距離を $22 \mathrm{~cm}$ 以下拈よび $250 \mathrm{kPa}$ 以上の 衝突压を得るには，垂直距離を $28 \mathrm{~cm}$ 以下にする必要 がある。

以上述べたように，とくに，一次スケールの脱スケー ルに必要な衝突圧は，二次スケールに比べてきわめて高 
Table 6. Impact force and pressure by hydraulicdescaling.

\begin{tabular}{|c|c|c|c|c|}
\hline $\begin{array}{l}\text { Reference } \\
\text { Scale }\end{array}$ & $\begin{array}{c}\text { Present work } \\
(\mathrm{kPa})\end{array}$ & $\begin{array}{c}\text { O. HENNIG et } a l^{7)} \\
(\mathrm{kPa})\end{array}$ & $\begin{array}{c}\text { H. HoJAs et al. } \\
(\mathrm{kPa})\end{array}$ & 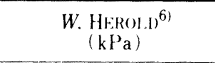 \\
\hline $\begin{array}{l}1 \text { st } \\
2 \text { nd }\end{array}$ & $\overline{35}$ & $\begin{array}{r}196 \sim 245 \\
49 \sim 78\end{array}$ & 410 & $\begin{array}{l}392 \sim 1960 \\
196 \sim 392\end{array}$ \\
\hline Steel used & Low carbon steels & $\begin{array}{l}\text { Carbon steels } \\
\text { Low alloy steels }\end{array}$ & $\begin{array}{l}\text { Carbon steels } \\
\text { High alloy steels }\end{array}$ & $\begin{array}{l}\text { Hot rolled steel sheets } \\
\text { Bar steels }\end{array}$ \\
\hline
\end{tabular}

Table 7. Some examples of impact pressure by hydraulic descaling on hot strip mills ${ }^{13)}$.

\begin{tabular}{c|c|c|c|c}
\hline \multicolumn{2}{c|}{ Condition } & $\mathrm{A}$ & $\mathrm{B}$ & $\mathrm{C}$ \\
\hline \multirow{4}{*}{$\mathrm{RSB}$} & $P(\mathrm{MPa})$ & 14.7 & 14.7 & 12.7 \\
& $V(\mathrm{l} / \mathrm{s})$ & 1.2 & 1.5 & 1.5 \\
& $H(\mathrm{~mm})$ & 690,300 & 613,348 & 470,220 \\
& $p(\mathrm{kPa})$ & 20,104 & 40,124 & 59,268 \\
\hline \multirow{6}{*}{$\mathrm{FSB}$} & $P(\mathrm{MPa})$ & 14.7 & 14.7 & 14.7 \\
& $V(1 / \mathrm{s})$ & 0.9 & 1.5 & 1.5 \\
& $H(\mathrm{~mm})$ & 275,165 & 285,225 & 190,190 \\
& $p(\mathrm{kPa})$ & 92,257 & 183,295 & 414,414 \\
\hline
\end{tabular}

いので，鋼種および目的に忍じて必要な衝突圧を確保す る適正脱スケール条件を選定することが肝要である。

\section{$4 \cdot 4$ 熱間圧延ラインの脱スケール設備の衝突圧}

次に，わが国の熱間压延ラインにおける脱スケール 設備 ${ }^{13)}$ の衝突压を検討する。ここで使用されている 脱スケール条件は，水压力が $14.7 \mathrm{MPa}$, ノズルが DNB0825－2325 抢よび垂值距離が約 20〜60 cm のもの が比較的に多い。これらの衝突压を式(4)から求めた結 果を Table 7 に示す.

これから，現状の熱間压延ラインにおける一次スケー ルの脱スケール設備での衝突压は約 20〜270 kPa で, とくに，上面側でやゃ低い。この值は，H. HENNIG ら ${ }^{7)}$ の低若素鋼および低合金鋼の場合に必要な衝突压の200 ～ $250 \mathrm{kPa}$ に比べてもやや低くなっている.

この理由として, 垂值距離の中に鋼材の厚みが含まれ ているものがあること，堅ロール(VSB) による一次 スケールの破壊作用が加味されていないことおよび完全 には脱スケールされない場令も压延によるスティッキン グおよびその後の脱スケールで除去されることなどが考 えられる。

お，一次スケールの場命の衝突臧は約 $30 \sim 400 \mathrm{kPa}$ で, H. HFNNIG $ら^{7)}$ の 50〜80 kPa に比べてゃや高く, とくに，仕上げ压延機入り側（FSB）での衝突压は約 $100 \sim 400 \mathrm{kPa}$ と高い.この理由は, FSBでの脱スケー ルは鋼板の表面品質への影響が大きいため，脱スケール 性を高めることに主眼を打いているためと考えられる。 しかし，衝突压を高くするとともに鋼材の温度低下も大 きくなると考えられるので, 脱スケール性を確保し, か つ、鋼材の温度低下を抑制するための適正脱スケール条
件を選走することが必要である。

\section{5. 結言}

高压水を噴射時の衝突压に及ほす荌四について，実験

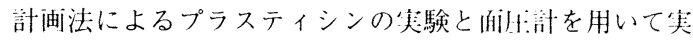
験を行い, 以下の結果を得た。

(1)高王: 水を噴射時のプラスティシンの脢み減少量 $\Delta t$ はノズル流量 $V$, 水打力 $P$, 通极速度 $v$ および舴过 距離 $H$ の 4 要因と相関関係が强い

( 2 )高压水によるプラスティシンの桨み減少量 $\Delta t$ 扮 よび衝突压: $p$ は各要因と次の実験式が成り方つ.

$$
\Delta t=2000 \mathrm{PV} /\left(v H^{2}\right)(\mathrm{cm})
$$

(重相関係数 $94 \%$ )

$$
p=5.64 P V / H^{2}(\mathrm{MPa})
$$

上記衝突后の式は，簢便かつ，是用的であり， $H$. HoJASらの式で求めた結果とよく・致する.

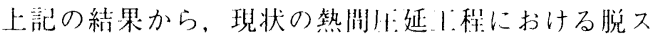
ケール条件を考祭したところ，下汒の検讨，䫎適化が必 要であることが判明した。

(1)一次スケールを除上するために必要な衝突压は, 次スケールに比べてきわめて高いので，その脱スケール 条件を設定する時には十分検討する必要がある。

(2)現状の熱延ラインでの衝突店は，とくにFSBでの 衝突压が高くなっている，そのため，脱スケールによる 鋼材の温度低下を抑制するための適正脱スケール条作の 検討が必要である.

最後に，本研究にあたって適切な御期にをいただいた 近畿大学理门学部教授令田進博士，新日本製鉄(株)第…

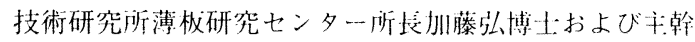
研究員秋末治博与:に深く感謝いたします.

\section{文献}

1) R. E. Tyцесоте: J. Iron Steel Inst., 195 (1960), p. 380

2 ) N. B. PII.IIng and R. E. BeidWorth: J. Inst. Met., 29 (1923), p. 529

3 ）松野一三朗: 鉄と銀，65 (1979), p. 599

4) T. Sheppard and W. M. Stren: J. Iron Steel Inst., 208 (1970), p. 797

5 ) H. Hojas and R. RhifinIt: Berg. Hüttenmann Monatsh, 112 (1967), p. 372

6) W. Herold): Bänder Bleche Rohre (1969), p. 279 
7) O. HenNig and G. ZwanzIG: Neue Hütte, 9 (1964), p. 361

8 ）柳下小太郎, 㧴本䪼浐, 江川康大, 大森舜二, 飯伏順一: 三菱重l技報, 11 (1974), p. 43

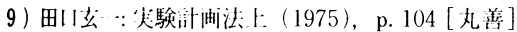

10）デスケーリングノズル宫) t 編) (1989 年. 10 月)
11）和田忠義，押見正一，上田正雄：鉄と銅，77（1991）, p. 1458

12）松野二三朗, 錦田俊一: 鉄と鋼, 71 (1985), S 1282

13）わが国における最近のホットストリップ製造技術（日本 鉄鐡協会編）（1987）, p. 396 